\title{
EVALUATION OF CIRCULATING MICROPARTICLES IN HEALTHY MEDICAL WORKERS OCCUPATIONALLY EXPOSED TO IONIZING RADIATION: A PRELIMINARY STUDY
}

GHASSAN AL-MASSARANI ${ }^{1}$, FADI NAJJAR ${ }^{1}$, ABDULMUNIM ALJAPAWE ${ }^{2}$, and ADNAN IKHTIAR ${ }^{2}$ Atomic Energy Commission of Syria (AECS), Damascus, Syria

${ }^{1}$ Biomarkers Laboratory, Department of Radiation Medicine

${ }^{2}$ Radiobiology Laboratory, Department of Molecular Biology and Biotechnology

\begin{abstract}
Objectives: Ionizing radiation was known to cause disruption of cytoskeleton. However, the disorganization of the cytoskeleton leads to form microparticles (MP) that carry membrane and cytoplasmic constituents from their parent cells they are released from. Therefore, authors investigated the effect of the occupational exposure to low doses of ionizing radiation on MP levels. Material and Methods: The current study was conducted on 38 healthy medical workers occupationally exposed to low doses of ionizing radiation and 29 controls matched by gender, age, and smoking habits. The MP levels measured by flow cytometry were classified as positive or negative phosphatidylserine ( $\mathrm{PS}^{+}$or $\mathrm{PS}^{-}$), and phenotyped according to their cellular origin. Results: Total MP $\left(\mathrm{PS}^{-} / \mathrm{PS}^{+}\right)$levels, regardless of phenotype, were significantly higher in workers occupationally exposed to ionizing radiation than in healthy individuals $(\mathrm{p}=0.0004)$. Negative phosphatidylserine microparticles were predominant in medical exposed workers and, to a lesser extent, in controls (68\% and 57\%, respectively). With regard to phenotypic characterization of cellular origin, MP derived from platelets (CD41a+), endothelial (CD146+), leucocytes $(\mathrm{CD} 45+)$ and erythrocytes $(\mathrm{CD} 235 \mathrm{a}+) \mathrm{MP}$ were significantly enhanced in exposed workers compared with controls ( $\mathrm{p}<0.0001)$. However, no significant difference was found in the proportion of the other blood elements in the peripheral circulation between the 2 groups. Serum levels of C-reactive protein were normal for all individuals. In addition, no association was observed between MP levels and the studied confounding factors. Conclusions: The results suggest that elevated circulating MP levels represent an indicator of cellular damage caused by medical exposure to low doses of ionizing radiation. By consequence, the quantification of MP seems to be a useful biomarker for assessing the negative effects of occupational exposure to ionizing radiation. Int J Occup Med Environ Health 2018;31(6):783-793
\end{abstract}

Key words:

Biomarkers, Flow cytometry, Occupational exposure, Microparticles, Ionizing radiation, Cellular damage

Received: August 22, 2016. Accepted: February 6, 2018.

Corresponding author: Ghassan Al-Massarani, Atomic Energy Commission of Syria (AECS), Biomarkers Laboratory, Department of Radiation Medicine,

P. O. Box 6091, Damascus, Syria (e-mail: galmassarani@aec.org.sy). 


\section{INTRODUCTION}

Human health risks induced by multiple circumstances of exposure including environmental, medical and ionizing radiation have been investigated. However, the risks resulting from the exposure to low doses of ionizing radiation remain ambiguous with intense debate. In fact, the relationship between chronic exposure to low doses of radiation and cardiovascular diseases is still currently scarce. It has been recently suggested that there is a probable association between cardiovascular diseases and exposure to low doses of ionizing radiation [1,2]. However, an increased incidence of such diseases has been well established after the exposure to high doses of ionizing radiation [3-5]. This increase maybe, in part, due to the deleterious effects of ionizing radiation on blood vessels [6]. Epidemiological studies are needed to clarify the possible relationship between exposure to ionizing radiation and vascular damage, which may contribute to understanding the risks on human health after chronic exposure to ionizing radiation. There are yet not truly satisfactory biological markers for evaluating the effects of low doses of ionizing radiation delivered over a long period of time [7]. Recently, it has been found that the incorporation of cellular biomarkers into epidemiological studies may be useful to develop new and more effective strategies for exposure monitoring, health surveillance and individual risk characterization. One of these relative recent advances in this field has been the discovery of the association between the circulating microparticles (MP) and cardiovascular diseases $[8,9]$.

Microparticles (MP) are small fragments $(0.1-1 \mu \mathrm{m})$ protruded from plasma membranes of virtually all cell types that are undergoing apoptosis or are being subjected to various types of stimulation or stress [10-12]. They contain cytosolic content surrounded by a phospholipid bilayer exposing several transmembrane proteins, which are specific for their cell origin. Previously, MP were identified by their positivity for phosphatidylserine (PS), but ample evi- dence now exists that not all MP express PS on their surface and the percentage that do varies with the method used for PS detection and the source of stimulation [13-16]. The amount of MP in the peripheral blood varies according to the physiological state and the pathological condition [17,18]. An increase in their absolute number has been reported in cardiovascular diseases, where MP have been implicated in activation of coagulation, induction of inflammatory response, and vascular dysfunction [19-23]. In vitro, it has been previously demonstrated that the irradiation of cells with a high dose of $\gamma$-rays leads to externalization of PS on the external leaflet of the plasma membrane of cells resulting in the formation of membrane blebs [24-26]. However, these observations have still been qualitative and not quantitative. By contrast, it has been quantitatively demonstrated that the irradiation of human peripheral blood mononuclear cells leads to increase procoagulant cells-derived MP [27].

In this study, authors hypothesized that the medical exposure to low doses of ionizing radiation would contribute to cell injury or activation initiated by a loss of phospholipid asymmetry and MP vesiculation. The effect of long-term medical occupational exposure to low doses of ionizing radiation on MP levels has been therefore investigated.

\section{MATERIAL AND METHODS}

\section{Study population}

The study was performed on 38 medical workers occupationally exposed to low doses of ionizing radiation at $\mathrm{Al}-$ Bairouni University Hospital and 29 healthy individuals, who had never been occupationally exposed to ionizing radiation. The exposed workers were matched by gender, age, and smoking habits with controls. All the individuals (workers and healthy subjects) lived in the same city and worked in suitable ventilated conditions. Individuals with infection, medication intake or medical X-ray exposure during the last 12 months were excluded from the study. An informed consent form was signed by all the partici- 
pants. Then, a structured questionnaire was conducted to collect data on sociodemographics, medical history, medication intake, and work-related factors. Socio-economic status (SES) information was not included in this study. The study protocol was approved by the local bioethical committee according to the guidelines prescribed by the Helsinki Declaration of the World Medical Association.

\section{Exposure monitoring}

The occupational exposure to $\gamma$-rays is routinely monitored using the thermo-luminescence dosimeter (TLD) as a passive radiation detection device (Thermo Scientific $^{\mathrm{TM}}$ Harshaw $^{\mathrm{TM}}$ Model 8800, Thermo Fisher Scientific, Waltham, MA, USA). The measured doses for the exposed medical workers were quarterly recorded during the period of their work.

\section{Blood sampling}

Peripheral blood samples were drawn at least $16 \mathrm{~h}$ after radiation exposure using a vacutainer tube containing $3.2 \%$ sodium citrate as an anticoagulant. The required criteria for handling the blood samples were applied in the study including transferring, freezing and thawing of the samples [28].

\section{C-reactive protein (CRP) assay}

Measurements of CRP in the peripheral blood samples were done by the hospital's clinical pathology laboratory using a standard assay.

\section{Isolation and quantification of MP}

As previously described [29,30], platelet-poor plasma (PPP) had been obtained within $4 \mathrm{~h}$ of collection using 2 serial centrifugations (15 min at $1500 \mathrm{~g}, 2 \mathrm{~min} 13000 \mathrm{~g}$ at $4^{\circ} \mathrm{C}$ ). Plasma had then been divided into $500 \mu \mathrm{l}$ aliquots, and stored at $-80^{\circ} \mathrm{C}$ until it was used. Samples were thawed at room temperature immediately before assay and were analyzed only after a single freeze-thaw cycle. Then $10 \mu$ of re-suspended PPP was added to $490 \mu \mathrm{l}$ of Annexin V binding buffer in a round bottom sterile tube and according to the manufacturers' instructions, it was incubated with $1 \mu \mathrm{l}$ of fluorescein isothiocyanate conjugated Annexin V (BioVision, Milpitas, CA, USA), CD41-PE (platelet derived MP; PMP, BD Biosciences, San Jose, CA, USA), CD45-PE (leukocyte derived MP; LMP, Miltenyi Biotec, Bergisch Gladbach, Germany), CD146-PE (endothelial derived MP; EMP, Miltenyi Biotec, Bergisch Gladbach, Germany) and CD235a-PE-Cy5 (erythrocyte derived MP; RMP, BD Biosciences, San Jose, CA, USA) in the dark for 5 min at room temperature.

The samples were analyzed on FACSCalibur ${ }^{\mathrm{TM}}$ flow cytometer controlled by CellQuest Pro 4.0.2 software (BD Bioscience, San Jose, CA, USA). As previously prescribed [31], the lower and upper limits of the MP were defined using a blend of mono-dispersed fluorescent beads $(0.5 \mu \mathrm{m}, 0.9 \mu \mathrm{m}$ and $3 \mu \mathrm{m})$ (Megamix, BioCytex, Diagnostica Stago, France) for better determination of MP location. Thus, the analyzed events represent the main part of the total MP in human plasma. Microparticles were defined as particles $<1.0 \mu \mathrm{m}$ in size and positive or negative to Annexin $\mathrm{V}$ and their cell origin as described above (Figure 1).

\section{Statistical analysis}

The population was divided into 2 groups according to the presence or absence of occupational exposure to ionizing radiation. Comparisons between groups were made using the Mann-Whitney $\mathrm{U}$ test and $\mathrm{Chi}^{2}$ test for continuous and nominal data, respectively. Using the Pearson correlations, the significant associations between MP and the TLD record were analyzed. The logistic regression analysis was applied to identify the independent association between the measured doses and MP values. Difference between variables was considered statistically significant at $p$ value $<0.05$. Data analysis was performed using Statistical Package for Social Sciences (SPSS) soft- 

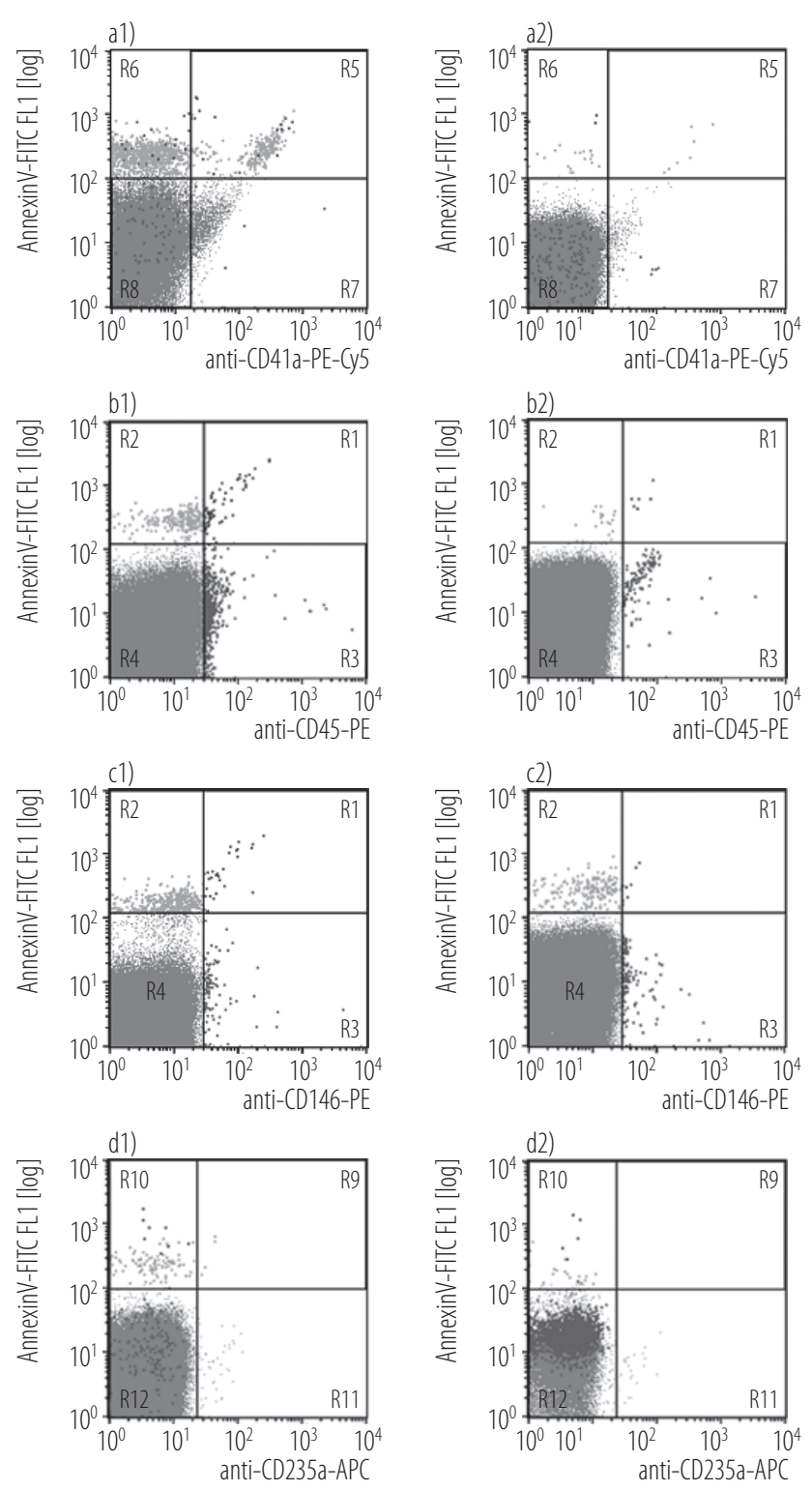

Various markers were used for detecting MPs originating from various cells: platelet-derived MP (PMP) were detected by CD41a and Annexin V; leukocyte-derived MP (LMP) were identified by phycoerythrin-CD45 and Annexin V; endothelial-derived (EMP) were identified by phycoerythrin-CD146 markers and Annexin V and erythrocytederived (RMP) were identified by CD235a markers and Annexin V.

Fig. 1. Identification of microparticles (MP) and their subpopulations using flow cytometry in medical exposed workers (1) and healthy controls (2):
a) platelet-derived MP (CD41a $\left.{ }^{+} \mathrm{PMP}\right)$,
b) leukocyte-derived MP (CD45 $\left.{ }^{+} \mathrm{LMP}\right)$,
c) endothelial-derived (CD146 $\left.{ }^{+} \mathrm{EMP}\right)$,
d) erythrocyte-derived (CD235a $\left.{ }^{+} \mathrm{RMP}\right)$

ware program for windows, version 15.0 (SPSS Inc., Chicago, IL, USA) and PRISM software (Graph Pad Inc., San Diego, CA, USA).

\section{RESULTS}

\section{Demographic data}

Thirty-eight workers (males: 34, females: 4) occupationally exposed to a low dose of ionizing radiation and 29 healthy individuals (males: 23, females: 6) were included in the study (Table 1). The mean age was 40 years (range 28-55 years) for the exposed medical workers and 37.24 years (range 25-51 years) for controls. The period of their employment was mean $(\mathrm{M}) \pm$ standard deviation (SD): $9.5 \pm 5.18$ years with an average yearly dose measured by TLD of $7.43 \mathrm{mSv}$ (range: $4.33-17.26 \mathrm{mSv}$ ). Controlled cardiovascular disease was reported for $2(5.3 \%)$ workers and $2(6.8 \%)$ healthy individuals. Furthermore, controlled diabetes and hypertension were observed in $2(5.3 \%)$ and $5(12.8 \%)$ exposed workers, respectively.

\section{Circulating microparticles characterization}

The amount of total MP (PS-/PS ${ }^{+}$) was approximately 5 times greater in the blood of medical exposed workers than that in controls $(p=0.0004)$ (Figure 2). Based on Annexin V binding, the population of MP was initially sub-grouped as particles positive for $\mathrm{PS}\left(\mathrm{PS}^{+}\right)$or negative for PS ( $\left.\mathrm{PS}^{-}\right)$. In medical exposed workers, a significant difference was found between the counts of PS-MP and $\mathrm{PS}^{+} \mathrm{MP}$ when analyzing total MP, PMP, EMP, LMP and RMP $(\mathrm{p}<0.05)$ (Figure 3). When expressed in terms of total MP, the percentage population of $\mathrm{PS}^{+} \mathrm{MP}$ represented $31 \pm 4.5 \%(\mathrm{M} \pm \mathrm{SD})$, and out of that $13.9 \pm 2.9 \%$ was derived from platelets, $8 \pm 1.6 \%$ from leucocytes, $6.4 \pm 1.18 \%$ - from endothelial cells, and $2.7 \pm 2.07 \%$ - from erythrocytes.

In a further comparison of the levels of the different MP phenotypes with those of controls, the data analy- 
Table 1. Demographic data and clinical characteristics of medical workers occupationally exposed to low doses of ionizing radiation and unexposed healthy individuals

\begin{tabular}{|c|c|c|}
\hline \multirow[b]{2}{*}{ Variable } & \multicolumn{2}{|c|}{ Respondents } \\
\hline & $\begin{array}{l}\text { medical workers } \\
\text { exposed to radiation } \\
(\mathrm{N}=38)\end{array}$ & $\begin{array}{l}\text { healthy individuals } \\
\qquad(\mathrm{N}=29)\end{array}$ \\
\hline Occupational exposure time [years] (Me (range)) & $9(1-22)$ & 0 \\
\hline Thermo-luminescence dosimeter (TLD) [mSv] (M (range)) & $7.43(4.33-17.26)$ & n.a. \\
\hline Age [years] $(\mathrm{M} \pm \mathrm{SEM})$ & $40.00 \pm 1.04$ & $37.24 \pm 1.49$ \\
\hline Male $[\%]$ & 89.50 & 79.31 \\
\hline Body mass index (BMI) (M \pm SEM) & $27.47 \pm 0.63$ & $26.39 \pm 0.75$ \\
\hline Smoking [\%] & 60.5 & 58.0 \\
\hline \multicolumn{3}{|l|}{ Medical history } \\
\hline cardiovascular disease & 2 & 2 \\
\hline diabetic disease & 2 & 0 \\
\hline hypertension & 5 & 1 \\
\hline cancer & 0 & 0 \\
\hline other & 5 & 4 \\
\hline \multicolumn{3}{|l|}{ Treatment } \\
\hline statin & 0 & 0 \\
\hline antihypertensive & 5 & 1 \\
\hline
\end{tabular}

Me - median; M - mean; SEM - standard error of the mean; n.a. - not applicable.

sis indicated that populations of MP (PMP, EMP, RMP and LMP), regardless of PS surface marker expression, are more abundant in exposed workers compared to controls $(p<0.0001)$. The relative abundance of PMP, LMP, EMP and RMP numbers in the case of the exposed workers was $56.6 \%, 20.1 \%, 17.2 \%$ and $6.1 \%$ of total MP, respectively.

However, there was no significant difference between the 2 groups in the mean values of basic hematological parameters including red blood cells $(p=0.76)$, white blood cells $(p=0.94)$, and platelets $(p=0.48)$. C-reactive protein levels were within the normal range (up to $6 \mathrm{mg} / \mathrm{l}$ ) for all individuals. Furthermore, no significant difference was found in the mean values of serum CRP levels between exposed and unexposed workers $(\mathrm{M} \pm \mathrm{SD}$ : $2.15 \pm 1.12 \mathrm{mg} / \mathrm{l}$ vs. $1.97 \pm 0.88, \mathrm{p}=0.63$ ).

The data analysis revealed that there was no significant change in total MP levels with gender, increasing age or body mass index (BMI) values. Similarly, no significant difference was obtained in the counts of MP between current smokers and non-smokers in the exposed group (mean \pm standard error of the mean (SEM): $3695 \pm 597 \mathrm{MP} / \mu \mathrm{l}$ vs. $2381 \pm 546, p=0.14)$. The multivariable regression analysis revealed that circulating MP levels were not significantly correlated to the other variables in the exposed group ( $p=0.21)$. Moreover, the period of occupational exposure to ionizing radiation was not significantly correlated with these variables. 


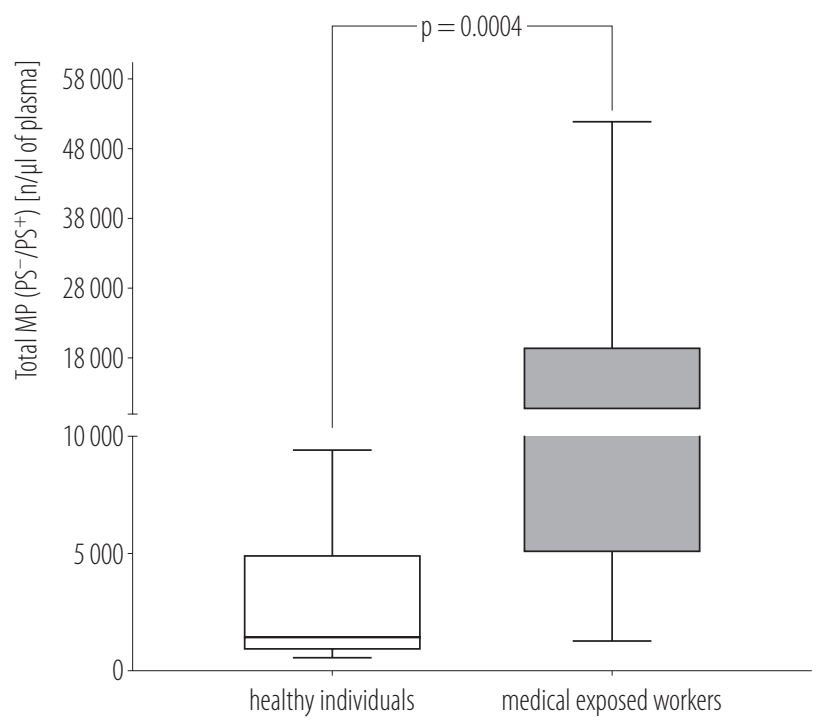

Mean values $(\mathrm{M})$ of total MP \pm standard error of the mean (SEM) in medical workers occupationally exposed to low-level ionizing radiation $(\mathrm{N}=38)$ compared with healthy individuals $(\mathrm{N}=29)$. Results are expressed as $\mathrm{M} \pm \mathrm{SEM}$ (total $\mathrm{PS}^{+} / \mathrm{PS}^{-} \mathrm{MP}$ number in $\mu \mathrm{l}$ of blood). Total MP levels were significantly higher in medical workers occupationally exposed to ionizing radiation than those in healthy individuals $(\mathrm{p}=0.0004)$.

Fig. 2. Levels of circulating total microparticles (MP) positive and negative for phosphatidylserine $\left(\mathrm{PS}^{-} / \mathrm{PS}^{+}\right)$in medical workers exposed to low doses of ionizing radiation and in healthy individuals

\section{DISCUSSION}

Strong evidence suggests MP as a biomarker of vascular injury. It may also contribute to the initiation and the development of atherosclerosis. In fact, several biological mechanisms might be responsible for atherosclerosis caused by radiation exposure even at a low dose. Therefore, the risk of developing cardiovascular diseases for individuals occupationally exposed to ionizing radiation remains a health concern. To the best of the knowledge, this is the first study which investigates the effect of the occupational exposure to low doses of ionizing radiation on circulating MP levels in vivo. In the current study, authors tried to assess the cellular membrane damage resulting from occupational exposure to low doses of ionizing radiation by quantification MP levels. The authors originally

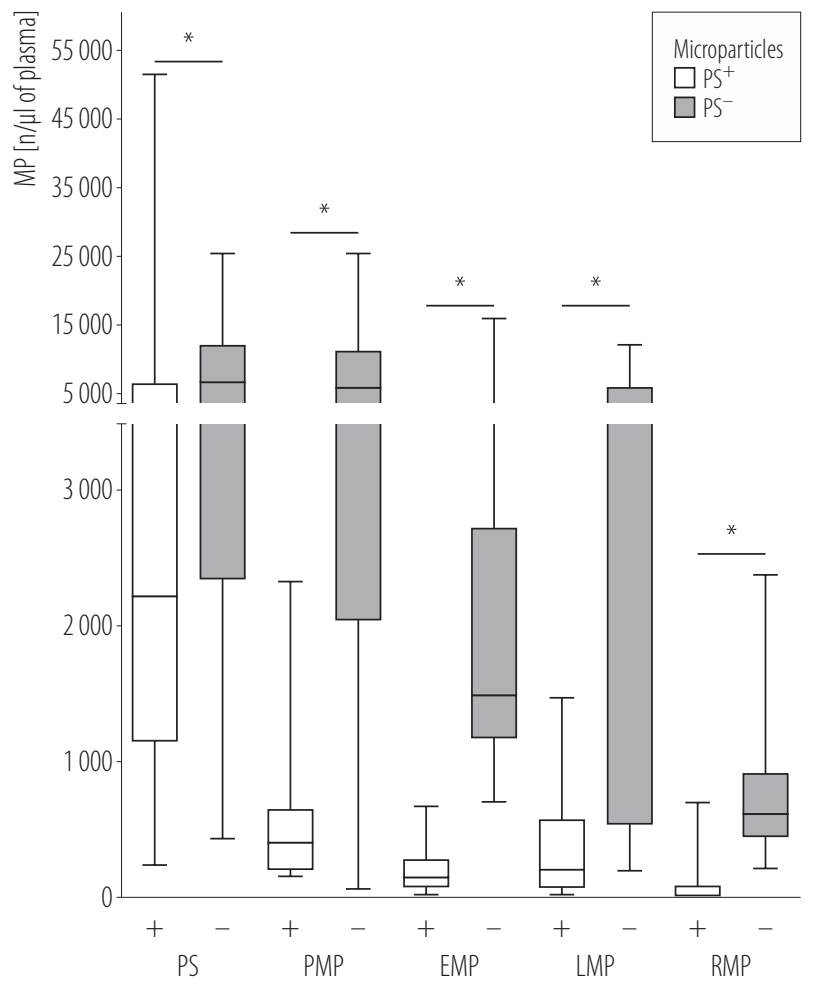

PS - phosphatidylserine.

Other abbreviations as in Figure 1.

Total MP ( $\left.\mathrm{PS}^{+} / \mathrm{PS}^{-}\right)$concentration and their subpopulations in medical workers $(\mathrm{N}=38)$ exposed to low doses of ionizing radiation were detected using flow cytometry and defined as particles $<1 \mu \mathrm{m}$ in size and either positive or negative for Annexin V-FITC. Subpopulation were then phenotyped according to cellular origin. Each group ( $\mathrm{PS}^{+}$vs. $\left.\mathrm{PS}^{-}\right)$was compared with t-test. $* \mathrm{p}<0.05$.

Fig. 3. Distribution of phosphatidylserine negative (PS-) and phosphatidylserine positive $\left(\mathrm{PS}^{+}\right)$total microparticles (MP) and their subpopulations in medical workers exposed to low doses of ionizing radiation

found that populations of MP, regardless of their phenotypes and phosphatidylserine expression, were significantly higher in workers occupationally exposed to low doses of ionizing radiation than those in controls.

The study has shown that the levels of both $\mathrm{PS}^{+}$and PS- $^{-}$MP are significantly increased in the peripheral blood of medical exposed workers. The MP number was not proportional to PS exposure and the minority of the MP exposed PS. Approximately 14\% of PMP were stained 
with Annexin V-FITC, which is in agreement with results obtained in previous studies [13,14].

In vivo, the exact primary biological mechanisms, the factors and stimuli that regulate secretion of microparticles have not yet completely understood, but roles have been reported in vitro for ionizing radiation [27]. The recent study has demonstrated a significant increase in externalization of PS in irradiated cells [32]. It has also been demonstrated that PS externalization was associated with the release of cellular MP [26], which may in part explain the high circulating levels of $\mathrm{PS}^{+}$MP in workers occupationally exposed to low doses of ionizing radiation.

The externalization of PS probably represents an early sign of dying cells [33]. Therefore, higher levels of PS ${ }^{+} \mathrm{MP}$ may reflect cellular apoptosis induced by long-term exposure to low doses of ionizing radiation. However, the predominant PS- MP at high levels in the study suggest that these vesicles probably originate from blood cells through an activation caused by long-term exposure to low doses of ionizing radiation. Horstman et al. [34], have observed that MP from activated endothelial cells are rarely positive for PS, in contrast to MP from apoptotic endothelial cells. Nevertheless, the biological importance of PS- MP is not yet known, and the importance of this phenomenon should be assessed by future studies.

In vitro and in vivo studies have shown that several mechanisms may have a relevant role in radiation-induced cardiovascular effects [35]. These effects include inflammation, oxidative stress, alterations of coagulation and platelet activity, DNA damage, cell death and endothelial dysfunction [36]. As shown in the previous study [37], authors found that PMP occupied the greatest percentage of circulating MP in the exposed workers.

Indeed, it has been demonstrated that this phenotype of MP binds to the sub-endothelial matrix causing endothelial damage [38]. However, it has previously been reported that occupational radiation exposure leads to an increase in circulating endothelial cells (CEC) [39]. This may be due, in part, to the endothelial dysfunction resulting from high PMP release after ionizing radiation.

Despite the heterogeneity of the measured doses of ionizing radiation, authors did not find an association between these measured doses and MP levels. This heterogeneity is probably due to the fact that these individuals had received a chronic radiation exposure during different periods of employment. However, the absence of such association could be explained by the small sample size, the lack of adjustment of some factors such as diet and SES information.

It should be noted that some biomarker responses appear to be linear with doses, while others are not [40]. Despite the elimination of MP from blood after $5.8 \mathrm{~h}$ (corresponding to their half-life) [41], the exposure to ionizing radiation may affect their levels. This suggestion could be supported by the fact that the lymphopenia (the decline in the lymphocytes count) following whole-body irradiation may persist for many years after exposure. However, in the absence of platelet activation, MP would need to be constantly shed from these platelets in order to produce MP in the plasma of healthy individuals. In pathological states including stress, the continuous production of MP overrides their rapid clearance. So elevated circulating MP levels could be expected. On the basis of these findings, increased MP levels appear to be a useful biomarker for radiation damage even for a long period after irradiation.

This study has demonstrated that blood cells counts in medical workers exposed to low doses of ionizing radiation remain within the normal range. Similar results have been reported in medical workers occupationally exposed to low doses of radiation [42]. However, previous studies suggest that the decline in blood cell counts after ionizing radiation significantly depends on the measured dose $[43,44]$. In fact, the measured doses in the medical workers were too low to cause a significant difference in the blood cells count between the 2 groups. However, it 
seems that hematological parameters survey could not be a reliable test as the biological indicator of long-term exposure to a low dose of ionizing radiation. Therefore, the cellular damage induced by the exposure to low doses of radiation, which has not been revealed by a change in the blood cells, could be reflected by increased circulating MP derived from these cells.

It has been suggested that occupational exposure to low doses of ionizing radiation was not associated with inflammation. However, circulating markers of inflammation, such as CRP, is not specific to a particular disease or exposure to low doses of ionizing radiation. For instance, it is modulated in the case of cancer, rheumatoid arthritis, cardiovascular diseases, or upon high doses of ionizing radiation [45]. In agreement with a previous study [46], authors found that there was no significant change in CRP concentrations between exposed workers to low doses of ionizing radiation compared to controls. These findings suggest that occupational exposure to low doses of ionizing radiation is not associated with inflammation.

Taken together, it may be assumed that medical occupational exposure to low doses of ionizing radiation leads to high levels of circulating populations of MP, which may probably indicate a susceptibility to radiation injury.

\section{CONCLUSIONS}

Results suggest circulating populations of MP as a useful biomarker for the detection of cellular membrane injury caused by long-term exposure to low doses of ionizing radiation. However, further prospective studies with a large cohort are warranted to investigate the possible correlation between total MP levels and the measured doses after the exposure to ionizing radiation.

\section{ACKNOWLEDGMENTS}

Special thanks to Mrs. Nissreen Almalla and Ms. Israa Banat for technical assistance.

\section{REFERENCES}

1. Little P, Azizova TV, Bazyka D, Bouffler SD, Cardis E, Chekin S, et al. Systematic review and meta-analysis of circulatory disease from exposure to low-level ionizing radiation and estimates of potential population mortality risks. Environ Health Perspect. 2012;120(11):1503-11, https://doi.org/10.1289/ehp. 1204982.

2. Zielinski JM, Ashmore PJ, Band PR, Jiang H, Shilnikova NS, Tait VK, et al. Low dose ionizing radiation exposure and cardiovascular disease mortality: Cohort study based on Canadian national dose registry of radiation workers. Int J Occup Med Environ Health. 2009;22(1):27-33 (cited Jul 20, 2016). Available from: http://www.imp.lodz.pl/upload/oficyna/artykuly/pdf/full/ 2009_01\%20Zielinski.pdf.

3. Little P, Moore MV, Turner S, Rumsby K, Warner G, Lowes JA, et al. Effectiveness of 5 different approaches in management of urinary tract infection: Randomised controlled trial. BMJ. 2010;340:c199, https://doi.org/10.1136/bmj.c199.

4. Baker JE, Fish BL, Su J, Haworth ST, Strande JL, Komorowski RA, et al. 10 Gy total body irradiation increases risk of coronary sclerosis, degeneration of heart structure and function in a rat model. Int J Radiat Biol. 2009;85(12):1089-100, https://doi.org/10.3109/09553000903264473.

5. Baker JE, Moulder JE, Hopewel JW. Radiation as a risk factor for cardiovascular disease. Antioxid Redox Signal. 2011;15(7):1945-56, https://doi.org/10.1089/ars.2010.3742.

6. Soloviev AI, Tishkin SM, Parshikov AV, Ivanova IV, Goncharov EV, Gurney AM. Mechanisms of endothelial dysfunction after ionized radiation: Selective impairment of the nitric oxide component of endothelium-dependent vasodilation. Br J Pharmacol. 2003;138(5):837-44, https://doi.org/10.1038/ sj.bjp.0705079.

7. Amundson SA, Bittner M, Meltzer P, Trent J, Fornace AJJR. Biological indicators for the identification of ionizing radiation exposure in humans. Expert Rev Mol Diagn. 2001;1(2):211-9, https://doi.org/10.1586/14737159.1.2.211.

8. Puddu P, Puddu GM, Cravero E, Muscari S, Muscari A. The involvement of circulating microparticles in inflammation, 
coagulation and cardiovascular diseases. Can J Cardiol.2010;26(4):140-5,https://doi.org/10.1016/S0828-282X(10) 70371-8.

9. Shantsila E, Kamphuisen PW, Lip GY. Circulating microparticles in cardiovascular disease: Implications for atherogenesis and atherothrombosis. J Thromb Haemost. 2010;8(11):2358-68, https://doi.org/10.1111/j.1538-78 36.2010.04007.x.

10. Freyssinet JM, Dignat-George F. More on: Measuring circulating cell-derived microparticles. J Thromb Haemos. 2005;3(3):613-4, https://doi.org/10.1111/j.1538-78 36.2004.00936.x.

11. Montoro-Garcia S, Shantsila E, Marin F, Blann A, Lip GY. Circulating microparticles: New insights into the biochemical basis of microparticle release and activity. Basic Res Cardiol. 2011;106(6):911-23, https://doi.org/10.1007/s00395011-0198-4.

12. Morel O, Jesel L, Freyssinet J-M, Toti F. Cellular mechanisms underlying the formation of circulating microparticles. Arterioscler Thromb Vasc Biol. 2011;31(1):15-26, https:// doi.org/10.1161/ATVBAHA.109.200956.

13. Nielsen MH, Beck-Nielsen H, Andersen MN, Handberg A. A flow cytometric method for characterization of circulating cell-derived microparticles in plasma. J Extracell Vesicles. 2014;3, https://doi.org/10.3402/jev.v3.20795.

14. Connor DE, Exner T, Ma DD, Joseph JE. The majority of circulating platelet-derived microparticles fail to bind annexin V, lack phospholipid-dependent procoagulant activity and demonstrate greater expression of glycoprotein $\mathrm{Ib}$. Thromb Haemost. 2010;103(5):1044-52, https://doi.org/10. 1160/TH09-09-0644.

15. Van Der Meijden PE, Van Schilfgaarde M, Van Oerle R, Renné T, ten Cate H, Spronk HM. Platelet- and erythrocytederived microparticles trigger thrombin generation via factor XIIa. J Thromb Haemost. 2012;10(7):1355-62, https:// doi.org/10.1111/j.1538-7836.2012.04758.x.

16. Chandler WL, Yeung W, Tait JF. A new microparticle size calibration standard for use in measuring smaller microparticles using a new flow cytometer. J Thromb Haemost. 2011;9(6):1216-24, https://doi.org/10.1111/j.1538-78 36.2011.04283.x.

17. Berckmans RJ, Nieuwland R, Boing AN, Romijn FP, Hack CE, Sturk A. Cell-derived microparticles circulate in healthy humans and support low grade thrombin generation. Thromb Haemost. 2001;85(4):639-46.

18. Burnier L, Fontana P, Kwak BR, Angelillo-Scherrer A. Cellderived microparticles in hemostasis and vascular medicine. Thromb Haemost. 2009;101(3):439-51.

19. Galindo-Hernandez O, Villegas-Comonfort S, Candanedo F, González-Vázquez MC, Chavez-Ocaña S, Jimenez-Villanueva $\mathrm{X}$, et al. Elevated concentration of microvesicles isolated from peripheral blood in breast cancer patients. Arch Med Res. 2013;44(3):208-14, https://doi.org/10.1016/j.arcmed. 2013.03.002.

20. Ling ZL, Combes V, Grau GE, King NJC. Microparticles as immune regulators in infectious disease. An opinion. Front Immunol. 2011;2:67, https://doi.org/10.3389/fimmu. 2011.00067.

21. Loyer X, Vion AC, Tedgui A, Boulanger CM. Microvesicles as cell-cell messengers in cardiovascular diseases. Circ Res. 2014;114(2):345-53, https://doi.org/10.1161/CIRCRESAHA.113.300858.

22. Pankoui Mfonkeu JB, Gouado I, Fotso Kuaté H, Zambou O, Amvam Zollo PH, Grau GE, et al. Elevated cell-specific microparticles are a biological marker for cerebral dysfunctions in human severe malaria. PLoS One. 2010;5(10):e13415, https://doi.org/10.1371/journal.pone.0013415.

23. Tushuizen ME, Diamant M, Sturk A, Nieuwland R. Cellderived microparticles in the pathogenesis of cardiovascular disease friend or foe? Arterioscler Thromb Vasc Biol. 2011;31(1):4-9, https://doi.org/10.1161/ATVBAHA.109. 200998.

24. Burt RK, Chen YH, Verda L, Lucena C, Navale S, Johnson J, et al. Mitotically inactivated embryonic stem cells can be used as an in vivo feeder layer to nurse damaged myocardium after acute myocardial infarction: A preclinical study. 
Circ Res. 2012;111(10):1286-96, https://doi.org/10.1161/ CIRCRESAHA.111.262584.

25. Claro S, Kanashiro CA, Oshiro ME, Ferreira AT, Khalil RA. Alpha- and epsilon-protein kinase $\mathrm{C}$ activity during smooth muscle cell apoptosis in response to gamma-radiation. J Pharmacol Exp Ther. 2007;322(3):964-72, https://doi. org/10.1124/jpet.107.125930.

26. Marconescu A, Thorpe PE. Coincident exposure of phosphatidyl ethanolamine and anionic phospholipids on the surface of irradiated cells. Biochim Biophys Acta. 2008;1778(10):2217-24, https://doi.org/10.1016/j.bba mem.2008.05.006.

27. Goldin-Lang P, Niebergall F, Antoniak S, Szotowski B, Rosenthal P, Pels K, et al. Ionizing radiation induces upregulation of cellular procoagulability and tissue factor expression in human peripheral blood mononuclear cells. Thromb Res. 2007;120(6):857-64, http://dx.doi.org/10.1016/j.throm res.2007.01.008.

28. Lacroix R, Judicone C, Poncelet P, Robert S, Arnaud L, Sampol J, et al. Impact of pre-analytical parameters on the measurement of circulating microparticles: Towards standardization of protocol. J Thromb Haemost. 2012;10(3):437-46, https://doi.org/10.1111/j.1538-7836.2011.04610.x.

29. Dignat-George F, Sabatier F, Camoin-Jau L, Sampol J. Measuring circulating cell-derived microparticles. J Thromb Haemos. 2004;2(10):1844-5, https://doi.org/10.1111/j.15387836.2004.00936.x.

30. Burnouf T, Goubran HA, Chou ML, Devos D, Radosevic M. Platelet microparticles: Detection and assessment of their paradoxical functional roles in disease and regenerative medicine. Blood Rev. 2014;28(4):155-66, https://doi. org/10.1016/j.blre.2014.04.002.

31. Robert S, Poncelet P, Lacroix R, Arnaud L, Giraudo L, Hauchard A, et al. Standardization of platelet derived microparticle counting using calibrated beads and a $\mathrm{Cy}$ tomics FC500 routine flow cytometer: A first step towards multicenter studies? J Thromb Haemost. 2009;7(1):190-7, https://doi.org/10.1111/j.1538-7836.2008.03200.x.
32. Zhao Z, Johnson MS, Chen B, Grace M, Ukath J, Lee VS, et al. Live-cell imaging to detect phosphatidylserine externalization in brain endothelial cells exposed to ionizing radiation: Implications for the treatment of brain arteriovenous malformations. J Neurosurg. 2015;124(6):1780-7, https://doi.org/10.3171/2015.4.JNS142129.

33. Bordón E, Henríquez-Hernández LA, Lara PC, Ruíz A, Pinar B, Rodríguez-Gallego $\mathrm{C}$, et al. Prediction of clinical toxicity in locally advanced head and neck cancer patients by radio-induced apoptosis in peripheral blood lymphocytes (PBLs). Radiat Oncol. 2010;5:4, https://doi.org/ 10.1186/1748-717X-5-4.

34. Horstman LL, Jy W, Jimenez JJ, Bidot C, Ahn YS. New horizons in the analysis of circulating cell-derived microparticles. Keio J Med. 2004;53(4):210-30, https://doi.org/10.2302/ kjm.53.210.

35. Baselet B, Rombouts C, Benotmane AM, Baatout S, Aerts A. Cardiovascular diseases related to ionizing radiation: The risk of low-dose exposure (Review). Int J Mol Med. 2016; 38(6):1623-41, https://doi.org/10.3892/ijmm.2016.2777.

36. Ardoin SP, Shanahan JC, Pisetsky DS. The role of microparticles in inflammation and thrombosis. Scand J Immunol. 2007;66(2-3):159-65, https://doi.org/10.1111/j.13653083.2007.01984.x.

37. Nieuwland R, Berckmans RJ, McGregor S, Böing AN, Romijn FP, Westendorp RG, et al. Cellular origin and procoagulant properties of microparticles in meningococcal sepsis. Blood. 2000;95(3):930-5.

38. Merten M, Pakala R, Thiagarajan P, Benedict CR. Platelet microparticles promote platelet interaction with subendothelial matrix in a glycoprotein IIb/IIIa-dependent mechanism. Circulation. 1999;99(19):2577-82, https://doi. org/10.1161/01.CIR.99.19.2577.

39. Al-Massarani G, Najjar F. Does occupational exposure to low ionizing radiation affect endothelium health? Nukleonika. 2013;58:527-31.

40. Deckbar D, Jeggo PA, Löbrich M. Understanding the limitations of radiation-induced cell cycle checkpoints. Crit Rev 
Biochem Mol Biol. 2011;46(4):271-83, https://doi.org/10.31 09/10409238.2011.575764.

41. Rank A, Nieuwland R, Crispin A, Grutzner S, Iberer M, Toth $\mathrm{B}$, et al. Clearance of platelet microparticles in vivo. Platelets. 2011;22(2):111-6, https://doi.org/10.3109/0953710 4.2010.520373.

42. Shafiee M, Hoseinnezhad E, Vafapour H, Borzoueisileh S, Ghorbani M, Rashidfar R. Hematological findings in medical professionals involved at intraoperative fluoroscopy. Glob J Health Sci. 2016;8(12):232-8, https://doi.org/10.5539/ gjhs.v8n12p232.

43. Sanzari JK, Cengel KA, Wan XS, Rusek A, Kennedy AR. Acute hematological effects in mice exposed to the expected doses, dose-rates, and energies of solar particle event-like proton radiation. Life Sci Space Res (Amst). 2014;2:86-91, https://doi.org/10.1016/j.lssr.2014.01.003.
44. Caciari T, Capozzella A, Tomei F, Nieto H, Gioffrè P, Valentini V, et al. Professional exposure to ionizing radiations in health workers and white blood cells. Ann Ig. 2011;24(6):465-74.

45. Pernot E, Hall J, Baatout S, Benotmane MA, Blanchardon E, Bouffler S, et al. Ionizing radiation biomarkers for potential use in epidemiological studies. Mutat Res. 2012;751(2): 258-86, https://doi.org/10.1016/j.mrrev.2012.05.003.

46. Kłuciński P, Mazur B, Kaufman J, Hrycek A, Cieślik P, Martirosian G. Assessment of blood serum immunoglobulin and $\mathrm{C}$-reactive protein concentrations in workers of $\mathrm{x}$-ray diagnostics units. Int J Occup Med Environ Health. 2005; 18(4):327-30 (cited Jul 20, 2016). Available from: http:// www.imp.lodz.pl/upload/oficyna/artykuly/pdf/full/Klu3-0405.pdf.

This work is available in Open Access model and licensed under a Creative Commons Attribution-NonCommercial 3.0 Poland License - http://creativecommons.org/ licenses/by-nc/3.0/pl/deed.en. 